\title{
O PODER DO PLANO DE NEGÓCIO
}

Congresso Nacional Online de Empreendedorismo, 3ạ edição, de 06/12/2021 a 08/12/2021 ISBN dos Anais: 978-65-81152-30-7

COUTINHO; Ana Paula Oppenheimer Coutinho 1, CARDIM; Ronaldo Luis Cardim 2, PAIVA; Victor Moura de Paiva ${ }^{3}$, AZEVEDO; Magno Santana Azevedo ${ }^{4}$, ÁVILA; Wellington 5

\section{RESUMO}

É possível compreender as etapas de construção de um plano de negócio como um conjunto de sinônimos que envolvem a imaginação, determinação, autoavaliação, habilidade de organização, liderança, gestão do conhecimento, apresentação dos pontos fracos e fortes, tudo isso unido com o potencial de minimizar e impedir alguma possibilidade de fracasso ou desperdício de tempo, além dos recursos financeiros. Assim o cidadão com o propósito de ter o próprio negócio com viabilidade de sucesso, prioritariamente deverá entender e por em prática um plano de negócio, visando nortear suas ações empreendedoras na obtenção do sucesso. De acordo com uma pesquisa no banco de dados do SEBRAE, $73 \%$ dos empreendimentos abertos no Brasil, conseguem caminhar bem e alcançar suas metas, diminuindo os riscos e as incertezas. O estudo proposto tem como objetivo analisar e apresentar o poder de um plano de negócio elaborado com qualidade abordando todo o desenho do negócio a ser desenvolvido. Foi realizada uma pesquisa bibliográfica especializada a partir de informações coletadas pelos autores com o propósito de analisar e apresentar o poder de um plano de negócio implantado. Logo, após a etapa anterior será apontada a análise de mercado, que terá a missão de identificar o público alvo do empreendimento, identificando tais clientes alvos, as concorrentes, os fornecedores, onde se encontram e quem é este público, fazendo uma análise de como o empreendimento caminhará, podendo assim produzir ações de marketing para conquista deste público alvo. Após a análise de mercado, espera-se que o empreendedor tenha como missão a verificação da qualidade e do custo benefício, que será o pensamento do produto, como ele será visto pelo mercado, mostrando os níveis satisfatórios alcançados para a sua entrega. Posteriormente, a operacionalidade e a parte financeira entrarão em análise para mostrar como a empresa será estruturada, sejam na sua localização, instalações e equipamentos, verificando o público alvo a ser atendida, a quantidade de funcionários necessários para o sucesso deste novo empreendimento, o planejamento orçamentário e de gestão. Após a implantação do plano de negócio, a tendência é que o empreendimento não sofra variações negativas, tal como os aspectos pertinentes à cultura local, a falta de educação financeira, a ausência de conhecimentos de gestão, tendências para o improviso, falta de vocação para o atendimento ao cliente e a pouca atenção com a qualidade, garantindo seu sucesso. Constatou-se que entender e planejar um plano de negócio no que se pretende ao seu empreendimento é a forma mais segura para obtenção de segurança e prosperidade empresarial. Sendo assim, ao buscar um plano de negócio, 
existirão recursos para compreender, identificar e controlar o negócio, que com tudo poderá caracterizar o crescimento e a evolução, fazendo assim necessário seu uso, para alcançar os objetivos.

PALAVRAS-CHAVE: Análise, Empreendimento, Planejamento, Plano de Negócio, Poder 